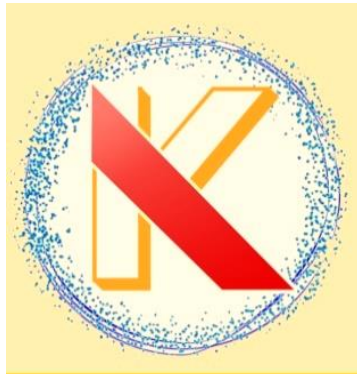

\title{
Analisis Kualitatif dan Kuantitatif Metabolit Sekunder Ekstrak Biji Kelor (Moringa oleifera Lam.) dengan Metode Spektrofotometri UV-Vis
}

\author{
[Qualitative and Quantitative Analysis of Secondary Metabolite of Moringa \\ Seed Extract (Moringa oleifera Lam.) with UV-Vis Spectrophotometry Method]
}

\author{
Tien Wahyu Handayani*, Yulistien Yusuf, Joni Tandi \\ Program studi S1 Faramasi, STIFA Pelita Mas Palu \\ ${ }^{*}$ Corresponding author: tienwahyu99@gmail.com
}

\begin{abstract}
This study aims to determine the content and total levels of secondary metabolites of ethanol extract of moringa seed (Moringa oleifera Lam.). Extraction of moringa seed using the maceration method to obtain a filtrate. The filtrate obtained was concentrated using a rotary evaporator to obtain a concentrated extract. The extract was tested qualitatively for alkaloids, flavonoids, saponins, and tannins using a suitable reagent with the test parameters. The quantitative test was using UV-Visible spectrophotometry. Alkaloids using test parameters equivalent total alkaloid quinine, flavonoids use parameter test equivalent of the total flavonoids quercetin, saponin using test parameters from Quillaja total saponins and tannins quantitative bark using test parameters total tannin tannic acid equivalent. The result showed that moringa seed positive for alkaloids characterized by orange deposition, flavonoids are characterized by the formation of the yellow color orange, saponin their stable foam, and tannins are marked in black. Quantitative test results alkaloids of $916,87 \mu \mathrm{g} / \mathrm{g}$, flavonoids of $0.255 \%$, saponin of $6.367 \%$, and tannin of $3,724.5 \mu \mathrm{g} / \mathrm{g}$.
\end{abstract}

Keywords: Moringa oleifera Lam., secondary metabolites, spectrophotometry

ABSTRAK. Penelitian ini bertujuan untuk mengetahui kandungan dan kadar total metabolit sekunder dari ekstrak etanol biji kelor (Moringa oleifera Lam.). Ektraksi biji kelor menggunakan metode maserasi dengan pelarut etanol $96 \%$ untuk mendapatkan filtrat. Filtrat yang diperoleh dipekatkan menggunakan rotary evaporator hingga diperoleh ekstrak pekat. Ekstrak yang diperoleh diuji kualitatif dengan uji Alkaloid, Flavonoid, Saponin dan Tanin dengan menggunakan pereaksi yang sesuai dengan parameter uji. Uji Kuantitatif menggunakan metode Spektrofotometri UV-Visible. Untuk alkaloid menggunakan parameter uji total alkaloid ekuivalen kuinin, flavonoid menggunakan parameter uji total flavonoid ekuivalen kuersetin, saponin menggunakan parameter uji total saponin dari Quilaja bark kuantitatif dan tanin menggunakan parameter uji total tanin ekuivalen asam tanat. Hasil uji kualitatif menunjukkan biji kelor positif mengandung alkaloid ditandai dengan adanya endapan orange, flavonoid ditandai dengan terbentuknya warna kuning jingga, saponin adanya busa yang stabil, dan tanin ditandai dengan warna hitam. Hasil uji kuantitatif, yaitu kadar alkaloid $916,87 \mu \mathrm{g} / \mathrm{g}$,flavonoid 0,255\%; saponin 6,367\%; dan tanin 3.724,5 $\mu \mathrm{g} / \mathrm{g}$.

Kata Kunci : Moringa oleifera Lam., metabolit sekunder, spektrofotometri

Riwayat artikel: Diterima 6 November 2020, Disetujui 18 Desember 2020

Cara sitasi: Hadayani, TW., Yusuf, Y., \& Tandi, J. (2020). Analisis Kualitatif dan Kuantitatif Metabolit Sekunder Ekstrak Biji Kelor (Moringa oleifera Lam.) dengan Metode Spektrofotometri UV-Vis. KOVALEN: Jurnal Riset Kimia, 6(3): 230-238.

DOI: https://doi.org/10.22487/kovalen.2020.v6.i3.15324 


\section{LATAR BELAKANG}

Jumlah tumbuhan berkhasiat obat di Indonesia diperkirakan sekitar 1.260 jenis tumbuhan. Setiap tumbuhan memiliki kandungan metabolit sekunder yang spesifik atau berbeda disetiap tumbuhan dengan fungsi yang juga berbeda-beda (Atun, 2010).

Metabolit sekunder dari tumbuhan dapat dimanfaatkan pada bidang farmakologi (Mustarichie, 2013 dalam Ergina et al., 2014), seperti berfungsi sebagai antioksidan, antikoagulan darah, antikanker, antibiotik, dan dapat menghambat efek karsiogenik. Jenisjenis senyawa metabolit sekunder meliputi flavonoid, alkaloid, terpenoid, steroid, saponin, tanin dan lainnya (Saxena \& Kalra, 2011). Salah satu tanaman yang memiliki metabolit sekunder yang banyak dimanfaatkan ialah tanaman kelor. Hampir seluruh bagian tanaman kelor dapat dimanfaatkan, baik sebagai sayur maupun sebagai obat.

Bagian daun dari tumbuhan kelor memiliki kandungan flavonoid yang memiliki aktivitas antioksidan (Salimi et al., 2017). Bagian lain dari tanaman kelor yang berpotensi memiliki senyawa metabolit sekunder yang dapat dimanfaatkan sebagai bahan obat ialah bagian biji. Anggi et al., (2020) sebelumnya melaporkan bahwa dalam ekstrak etanol biji kelor terdapat kandungan flavonoid 1,26\%, namun demikian tidak terdapat informasi lebih lengkap mengenai kandungan senyawa metabolit sekunder lainnya, sehingga perlu kajian tentang jenis dan kadar metabolit sekunder dalam biji kelor, baik secara kualitatif maupun kuantitatif.

\section{METODE PENELITIAN}

\section{Bahan dan Peralatan}

Bahan yang dipergunakan meliputi akuades, $\mathrm{AlCl}_{3} 10 \%$, anisaldehid, buffer phospat, dietil eter, biji kelor (Moringa oleifera Lam.), etanol $96 \%$, eter, gas Nitrogen, $\mathrm{HCl} 2 \mathrm{~N}$ dan $4 \mathrm{~N}, \mathrm{HCl}$ pekat, $\mathrm{H}_{2} \mathrm{SO}_{4} 20 \%$ dan $25 \%$, kertas saring, kloroform, kuinin, kursetin, larutan BCG, Metanol, $\mathrm{NaOH} 0,1$ dan $1 \mathrm{~N}$, natrium karbonat $20 \%$, natrium nitrit $5 \%$, pereaksi besi (III) klorida $\left(\mathrm{FeCl}_{3}\right)$, pereaksi dragendorff LP, pereaksi mayer, pereaksi wagner, reagen folin crocalteu, serbuk magnesium, tannic acid.

Peralatan yang digunakan berupa autoklaf, ayakan nomor 40 mesh, batang pengaduk, blender, cawan porselin, corong kaca, erlenmeyer, gelas kimia, gelas ukur, labu ukur, inkubator, rotary vakum evaporator, pengaduk magnet, stopwatch, tabung reaksi, labu ukur, timbangan analitik, wadah maserasi, waterbath, spektrofotometer UV- Vis evolition 201, vortex, timbangan analitik, dan timbangan kasar.

\section{Prosedur Penelitian}

\section{Pembuatan ekstrak etanol biji kelor (Moringa oleifera Lam.)}

Pembuatan ekstrak biji kelor menggunakan metode maserasi (Anggi et al., 2020) dengan cara serbuk simplisia ditimbang sebanyak 600 gram lalu dimasukkan ke dalam bejana maserasi dengan menggunakan pelarut etanol $96 \%$ sebanyak $2 \mathrm{~L}$, lalu dibiarkan selama $3 \times 24$ jam terlindung dari cahaya sambil sesekali diaduk. Ekstrak kental cair yang diperoleh dipekatkan dengan menggunakan rotavapor hingga menjadi ekstrak kental. Kemudian ekstrak kental ditimbang dan dihitung rendamennya.

$$
\text { Rendemen }=\frac{\text { Berat ekstrak kental }(g)}{\text { Berat sampel }(g)} \times 100 \ldots \ldots \ldots .(1)
$$

\section{Analisis kualitatif (Harborne et al., 2006)}

a. Uji flavonoid

Ekstrak biji buah kelor (Moringa oleifera Lam.) ditimbang sebanyak 0,5 gram lalu 
dimasukkan dalam tabung reaksi, ditambahkan $10 \mathrm{ml}$ aquadest, $5 \mathrm{ml}$ larutan amonia dan $1 \mathrm{ml}$ asam sulfat. Perubahan warna menjadi warna kuning menunjukkan adanya flavonoid.

b. Uji saponin

Ekstrak biji buah kelor (Moringa oleifera Lam.) ditimbang sebanyak 0,5 gram dimasukkan ke dalam tabung reaksi, lalu ditambahkan $10 \mathrm{ml}$ air panas, dinginkan kemudian dikocok dengan kuat selama 10 detik. Jika terbentuk buih yang menetap selama tidak kurang dari 1 menit setinggi 10 $\mathrm{cm}$ atau pada penambahan 1 tetes asam klorida $2 \mathrm{~N}$ buih tidak hilang maka menunjukkan adanya saponin.

c. Uji alkaloid

Ekstrak biji buah kelor (Moringa oleifera Lam.) ditimbang sebanyak 0,5 gram lalu ditambahkan $5 \mathrm{ml}$ asam klorida $2 \mathrm{~N}$ dan dipanaskan di atas penangas air selama 2 menit lalu ditambahkan 3 tetes pereaksi Dragendrof LP. Jika hasil memberikan endapan kuning orange sampai merah bata maka sampel mengandung alkaloid.

d. Uji tanin

Ekstrak biji buah kelor (Moringa oleifera Lam.) ditimbang sebanyak 0,5 gram dimasukkan ke dalam cawan lalu ditambahkan dengan $20 \mathrm{ml}$ air panas dan larutan $\mathrm{NaCl} 10 \%$ sebanyak 3 tetes. Kemudian ditambahkan larutan $\mathrm{FeCl}_{3}$, bila terbentuk warna biru hitam menunjukkan adanya tanin.

\section{Analisis kuantitatif}

\section{a. Uji kadar total flavonoid}

1. Pembuatan kurva standar

Ditimbang larutan baku standar quercetin $10 \mathrm{mg}$ ditambahkan 0,3 $\mathrm{ml}$ natrium nitrit 5\%. Setelah 5 menit, ditambahkan 0,6 $\mathrm{ml}$ aluminium klorida 10\%, tunggu 5 menit, kemudian ditambahkan $2 \mathrm{ml} \mathrm{NaOH} 1 \mathrm{M}$. Setelah itu addkan dengan aquades hingga $10 \mathrm{ml}$ dengan labu takar. Kemudian dipindahkan ke dalam kuvet, lalu menetapkan serapan pada panjang gelombang $510 \mathrm{~nm}$.

2. Penetapan uji total flavonoid

Diambil $0,10 \mathrm{~g}$ sampel uji dan ditambahkan $2 \mathrm{ml} \mathrm{HCl} 4 \mathrm{~N}$. Autoklaf selama 2 jam dengan suhu $110{ }^{\circ} \mathrm{C}$. Dinginkan, lalu ektraksi dengan eter, masukkan dalam tabung reaksi $10 \mathrm{ml}$. Uapkan eter, kemudian keringkan dengan gas $\mathrm{N}_{2}$. Ditambahkan 0,3 $\mathrm{ml}$ natrium nitrit 5\%. Setelah 5 menit tambahkan 0,6 $\mathrm{ml}$ aluminium klorida 10\%, tunggu 5 menit, lalu tambahkan $2 \mathrm{ml} \mathrm{NaOH}$ $1 \mathrm{M}$. Kemudian addkan dengan aquades hingga $10 \mathrm{ml}$ dengan labu takar. Dilakukan pengenceran sebanyak 25x. Pindahkan ke dalam kuvet, menetapkan serapan pada panjang gelombang $510 \mathrm{~nm}$.

Total flavonoid $\left(\% \frac{\mathrm{b}}{\mathrm{b}}\right)$

$=\frac{\text { hasil pembacaan }(\mathrm{ppm}) \times \text { vol.add akhir }(\mathrm{ml})}{\text { massa sampel }(\mathrm{g})} \div 10000$

\section{b. Uji kadar total saponin}

1. Pembuatan kurva standar

Ditimbang larutan standar saponin $10 \mathrm{mg}$ dan ditambahkan air sebanyak $5 \mathrm{ml}$ kemudian ekstraksi dengan vortex selama 5 menit. Lalu ditambahkan $50 \mu$ anisaldehid dan kocok. Diamkan selama 10 menit kemudian tambahkan $2 \mathrm{ml}$ asam sulfat $50 \%$. Panaskan pada penangas air pada suhu $60^{\circ} \mathrm{C}$ selama 10 menit dan ditambahkan air hingga volume $10 \mathrm{ml}$ dengan labu takar. Diencerkan larutan standar mulai dari 200; 100; 50; 25; 12,5; 6,25 $\mu \mathrm{l}$. kemudian 
membaca serapan pada panjang gelombang $435 \mathrm{~nm}$.

2. Penetapan uji total saponin

Ditimbang $100 \mathrm{mg}$ sampel dan ditambahkan $2 \mathrm{ml} \mathrm{H}_{2} \mathrm{SO}_{4}$ 25\%. Autoclave selama 120 menit, dengan suhu $110{ }^{\circ} \mathrm{C}$. Ekstraksi dengan eter lalu mengeringkan filtrat. Kemudian ditambahkan air sebanyak $1 \mathrm{ml}$ dan ekstraksi dengan vortex selama 5 menit. Tambahkan $50 \mu$ anisaldehid, kocok kemudian diamkan selama 10 menit. Tambahkan $2 \mathrm{ml}$ asam sulfat $50 \%$ dan panaskan dengan penangas air pada suhu $60{ }^{\circ} \mathrm{C}$ selama 10 menit. Kemudian ditambahkan air hingga volume $10 \mathrm{ml}$ dengan labu takar. Diencerkan sebanyak 10x dan membaca serapan pada panjang gelombang $435 \mathrm{~nm}$.

Total saponin $\left(\% \frac{\mathrm{b}}{\mathrm{b}}\right)$

$=\frac{\text { hasil pembacaan }(\mathrm{ppm}) \times \text { vol.add akhir }(\mathrm{ml})}{\text { massa sampel }(\mathrm{g})} \div 10000$

\section{c. Uji kadar total alkaloid}

1. Pembuatan kurva standar

Ditimbang larutan standar kuinin sebanyak $10 \mathrm{mg}$ dan ditambahkan $5 \mathrm{~mL} \mathrm{HCl}$ $2 \mathrm{~N}$, kocok kemudian saring. Mencuci larutan dengan $10 \mathrm{ml}$ kloroform sebanyak 3 kali dalam corong pisah, buang fase kloroform. Netralkan larutan dengan menambahan $\mathrm{NaOH}$ 0,1 N. Tambahkan 5 $\mathrm{ml}$ larutan BCG dan $5 \mathrm{ml}$ Buffer Phosphat, lalu ekstraksi larutan dengan 5 ml klofororm, aduk menggunakan pengaduk magnet dengan kecepatan 500 rpm selama 15 menit. Ulangi ekstraksi dengan kloroform sebanyak 2 kali dan kumpulkan fase kloroform, evaporasikan dengan gas Nitrogen, kemudian tambahkan dengan kloroform hingga volume $10 \mathrm{ml}$. Encerkan dan baca serapan pada panjang gelombang $470 \mathrm{~nm}$.

2. Penetapan uji total alkaloid

Ditimbang sampel uji sebanyak $\pm 100 \mathrm{mg}$ dan ditambahkan $5 \mathrm{ml} \mathrm{HCl} 2 \mathrm{~N}$, kocok lalu mencuci larutan dengan $10 \mathrm{ml}$ kloroform sebanyak 3 kali dalam corong pisah. Buang fase kloroform dan netralkan larutan dengan menambahan $\mathrm{NaOH} \quad 0,1 \quad \mathrm{~N}$. Kemudian tambahkan $5 \mathrm{ml}$ larutan BCG dan $5 \mathrm{ml}$ Buffer Phosphat. Ekstraksi larutan dengan 5 ml kloroform, aduk menggunakan pengaduk magnet dengan kecepatan 500 rpm selama 15 menit. Mengulang ekstraksi dengan kloroform sebanyak 2 kali dan kumpulkan fase kloroform. Evaporasikan dengan gas Nitrogen,kemudian addkan dengan kloroform hingga volume $5 \mathrm{ml}$. Membaca serapan pada panjang gelombang $470 \mathrm{~nm}$.

\section{d. Uji kadar total tanin}

1. Pembuatan kurva standar

Ditimbang larutan standar Tannic Acid sebanyak $1 \mathrm{mg}$ lalu tambahkan dengan 10 $\mathrm{ml}$ reagen Folin Ciocalteu dan divortex, tunggu 5 menit. Kemudian ditambahkan dengan larutan natrium karbonat $20 \%$, menepatkan volumenya sampai $100 \mathrm{ml}$. dilakukan pengenceran sesuai konsentrasi kurva standar Tannic Acid. Membaca absorbansi pada panjang gelombang 760 $\mathrm{nm}$ setelah diinkubasi selama 30 menit pada suhu kamar.

2. Penetapan uji total tanin

Ditimbang sampel sebanyak $\pm 100 \mathrm{mg}$, lalu ekstraksi dengan $10 \mathrm{ml}$ metanol selama 20 jam, kemudian saring. Uapkan sisa methanol dan tambahkan aquadest ke dalam sampel hingga volume $10 \mathrm{ml}$. Diambil $1 \mathrm{ml}$ larutan sampel dan ditambahkan dengan $0,1 \mathrm{ml}$ reagen Folin Ciocalteu dan 
vortex, tunggu 5 menit. Kemudian ditambahkan dengan $2 \mathrm{ml}$ Natrium Carbonat $20 \%$ dan vortex, tunggu 5 menit. Addkan dengan Aquadest hingga volume $10 \mathrm{ml}$ dan lakukan pengenceran sebanyak 5 kali. Membaca absorbansi pada panjang gelombang $760 \mathrm{~nm}$ setelah diinkubasi selama 30 menit pada suhu kamar (Chanwitheesuk et al., 2005).

\section{HASIL DAN PEMBAHASAN}

Penelitian ini menggunakan sampel biji kelor yang diperoleh di wilayah kecamatan Palu Selatan Sulawesi Tengah. Biji kelor sebelumnya telah diidentifikasi dengan tujuan memastikan bahwa tanaman yang digunakan tersebut benar (Moringa oleifera Lam.). Metode ekstraksi yang digunakan adalah metode maserasi dengan menggunakan pelarut etanol $96 \%$. Pelarut dipilih sebagai cairan penyari karena tidak beracun, netral, absorbsinya baik.

Analisis kualitatif metabolit sekunder dilakukan pada ekstrak kental, yaitu berupa uji penapisan fitokimia menggunakan tes warna dengan beberapa pereaksi untuk golongan senyawa alkaloid, flavonoid, tanin, dan saponin. Sementara itu, analisis kuantitatif atau penentuan kadar total senyawa-senyawa metabolit sekunder yang terkandung dalam ekstrak etanol biji kelor (Moringa oleifera Lam.) menggunakan metode Spektrofotometri UVVis. Penentuan kadar total yang dilakukan yaitu penentuan kadar total senyawa alkaloid, flavonoid, saponin dan tanin yang terdapat pada ekstrak etanol biji kelor (Moringa oleifera Lam.) berdasarkan pada kurva baku larutan standar masing- masing senyawa.

\section{Kandungan Senyawa Alkaloid}

Berdasarkan uji kualitatif dan kuantitatif pada ekstrak kental biji kelor (Moringa oleifera
Lam.) diperoleh hasil positif mengandung alkaloid pada uji Dragendroff ditandai dengan terbentuknya endapan kalium alkaloid (Tabel 1, Gambar 1).

Tabel 1. Hasil uji penapisan fitokimia ekstrak etanol biji kelor (Moringa oleifera Lam.).

\begin{tabular}{cccc}
\hline Pengujian & Pereaksi & Pengamatan & Hasil \\
\hline $\begin{array}{cccc}\text { Uji } \\
\text { Flavonoid }\end{array}$ & $\begin{array}{c}\text { HCL pekat } \\
\text { dan logam } \\
\mathrm{Mg}\end{array}$ & $\begin{array}{c}\text { Terdapat } \\
\text { endapan }\end{array}$ & $(+)$ \\
Uji & $\begin{array}{c}\text { Dikocok }+ \\
\text { Saponin } \\
\text { HCl 2 N }\end{array}$ & $\begin{array}{c}\text { Terbentuk } \\
\text { buih }\end{array}$ & $(+)$ \\
Uji & $\begin{array}{c}\text { Dragendorf } \\
\text { LP }\end{array}$ & $\begin{array}{c}\text { Terbentuk } \\
\text { endapan }\end{array}$ & $(+)$ \\
Alkaloid & Terbentuk & $(+)$ \\
Uji Tanin & $\mathrm{FeCl}_{3}$ & $\begin{array}{c}\text { warna hitam } \\
\text { wern }\end{array}$ \\
\hline
\end{tabular}

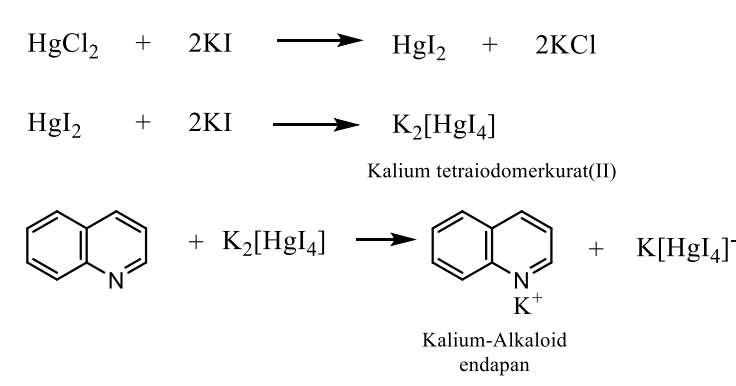

Gambar 1. Reaksi uji dragendroff (Ergina et al., 2014)

Pada pembentukan pereaksi Dragendroff, terjadi pelarutan bismut nitrat dalam $\mathrm{HCl}$ agar garam-garam bismut tidak terhidrolisis menjadi ion bismutil $\left(\mathrm{BiO}^{+}\right)$, seabagaiman persamaan berikut:

$$
\mathrm{Bi}^{3+}+\mathrm{H}_{2} \mathrm{O} \longrightarrow \mathrm{BiO}^{+}+2 \mathrm{H}^{+}
$$

Ion $\mathrm{Bi}^{3+}$ bereaksi dengan $\mathrm{KI}$ membentuk endapan hitam bismut (III) iodida dan terlarut dalam KI berlebih sehingga terbentuk kalium tetraiodobismutat. Penggunaan nitrogen pada uji alkaliod dimaksudkan untuk membentuk ikatan kovalen koordinat dengan $\mathrm{K}^{+}$.

Kurva standar alkaloid dimanfaatkan untuk menentukan kadar alkaloid dalam sampel 
ekstrak etanol biji kelor. Pada kurva standar alkaloid diperoleh persamaan regresi $y=0,0002 x-0,0005$ dan koefisien korelasi $\left(r^{2}\right)$ 0,9939 (Gambar 2).

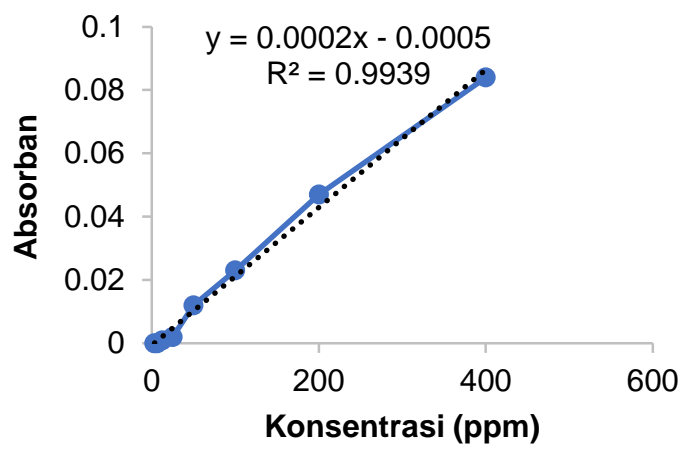

Gambar 2. Kurva standar alkaloid

Berdasarkan persamaan regresi tersebut, dilakukan perhitungan kadar alkaloid total dengan parameter uji total alkaloid ekuivalen kuinin diperoleh kadar alkaloid pada sampel ekstrak etanol biji kelor (Moringa oleifera Lam.) yaitu 916,87 $\mu \mathrm{g} / \mathrm{g}$ (Tabel 2). Alkaloid memiliki aktivitas farmakologis antara lain sebagai analgesik, antimalaria dan sebagai anastesi lokal (Hanani, 2014).

Tabel 2. Hasil penentuan kadar ekstrak etanol biji kelor (Moringa oleifera Lam.)

\begin{tabular}{ccc}
\hline No & Parameter Uji & Hasil \\
\hline 1. & Total alkaloid & 916,87 \\
ekuivalen quinine & $\mu \mathrm{g} / \mathrm{g}$ \\
2. & $\begin{array}{c}\text { Tanin total ekuivalen } \\
\text { tannic acid }\end{array}$ & $\begin{array}{c}3.724,5 \\
\mu \mathrm{g} / \mathrm{g}\end{array}$ \\
3. & $\begin{array}{c}\text { Saponin from quillaja } \\
\text { bark kuantitatif }\end{array}$ & $6,367 \%$ \\
4. & Total flavonoid & $0,255 \%$ \\
\hline
\end{tabular}

\section{Kandungan Senyawa Tannin}

Ekstrak etanol bji kelor (Moringa oleifera Lam.) positif mengandung tanin yang ditandai dengan larutan berwarna hitam setelah ditambahkan larutan $\mathrm{FeCl}_{3}$ (Tabel 1), hal ini dikarenakan adanya salah satu senyawa fenol yaitu tanin yang terdapat dalam sampel membentuk senyawa kompleks dengan ion $\mathrm{Fe}^{3+}$.

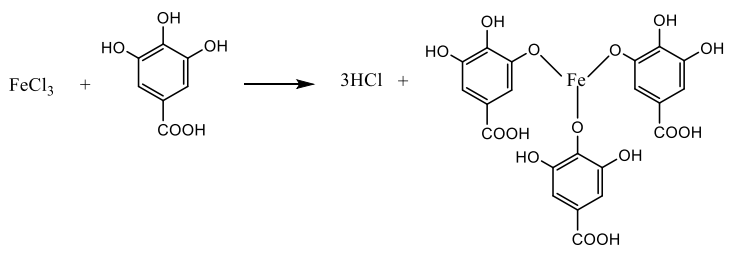

Gambar 3. Reaksi antara tanin/ polifenol dan $\mathrm{FeCl}_{3}$ (Simaremare, 2014)

Pada uji kuantitatif kadar tanin diperoleh persamaan regresi senyawa saponin yaitu $y=$ $0,0423 x+0,0033$ dengan koefisien korelasi $\left(r^{2}\right)$ yaitu 0,9999 (Gambar 4).

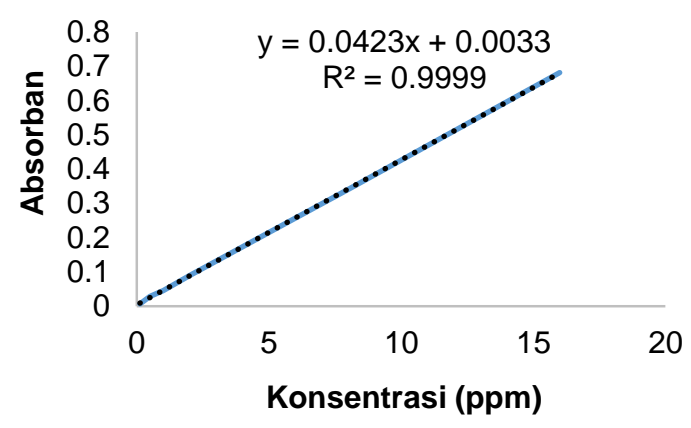

Gambar 4. Kurva standar tanin

Kadar senyawa tanin dengan parameter uji total tanin ekuivalen asam tanat diperoleh kadar total untuk kadar total tanin, yaitu 3.724,5 $\mu \mathrm{g} / \mathrm{g}$ (Tabel 2). Sifat tanin sebagai astringen dapat dimanfaatkan sebagai antidiare, menghentikan perdarahan, dan mencegah peradangan terutama pada mukosa mulut, serta digunakan sebagai antiseptik karena adanya gugus fenol (Hanani, 2014).

\section{Kandungan Senyawa Saponin}

Hasil analisis kualitatif ekstrak etanol bji kelor (Moringa oleifera Lam.) positif mengandung saponin yang ditandai terbentuknya buih pada saat sampel ditambahkan $\mathrm{HCl}$ lalu dikocok (Tabel 1). Terbentuknya koloid buih dikarenakan saponin memiliki dua jenis gugus berbeda, yaitu 
hidrofilik dan hidrofobik. Larutan $\mathrm{HCl}$ berfungsi untuk meningkatkan kepolaran campuran sehingga interaksi gugus hidrofil saponin dan air akan lebih stabil dan buih yang terbentuk juga menjadi lebih stabil.

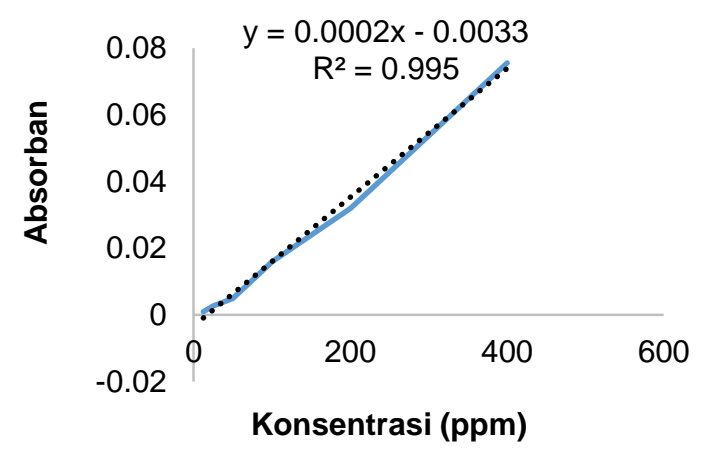

Gambar 5. Kurva standar saponin

Pada kurva standar saponin, diperoleh persamaan regresi $y=0,0423 x+0,0033$ dan koefisien korelasi $\left(r^{2}\right)$ yaitu 0,995 (Gambar 5). Kadar saponin total ekstrak etanol biji kelor berdasarkan kurva regeresi dengan parameter uji total saponin dari Quillaja bark kuantitatif, yaitu $6,367 \%$ (Tabel 2). Saponin memiliki aktivitas farmakologi antara lain dapat menurunkan kolestrol, mempunyai sifat sebagai antioksidan, antivirus dan anti karsinogenik (Hanani, 2014).

\section{Kandungan Senyawa Flavonoid}

Hasil uji kualitatif senyawa flavonoid terhadap ekstrak etanol bji kelor (Moringa oleifera Lam.) dengan menggunakan pereaksi $\mathrm{HCl}$ dan logam $\mathrm{Mg}$ diperoleh hasil positif mengandung flavonoid yaang ditandai dengan terbentuknya larutan berwarna kuning (Tabel 1).

Penambahan logam $\mathrm{Mg}$ dan $\mathrm{HCl}$ pada proses identifikasi bermaksud untuk mereduksi inti benzopiron dalam struktur flavonoid sehingga akan terbentuk garam flavilium (Gambar 6).

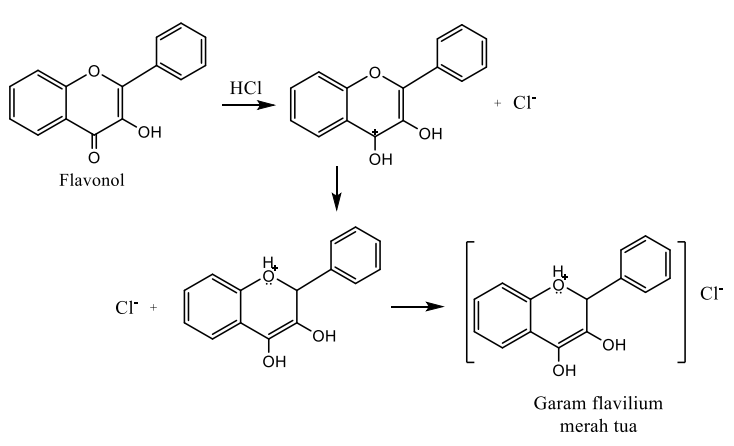

Gambar 6. Reaksi flavonoid dengan $\mathrm{HCl}$ dan logam Mg (Septyaningsih, 2010).

Penentuan kadar flavonoid menggunakan kuersetin sebagai kurva baku standar sehingga diperoleh pesamaan regresi yaitu $\mathrm{y}=0,0046 \mathrm{x}+$ 0,0023 dan koefisien korelasi $\left(r^{2}\right)$ yaitu 0,9995 (Gambar 7).

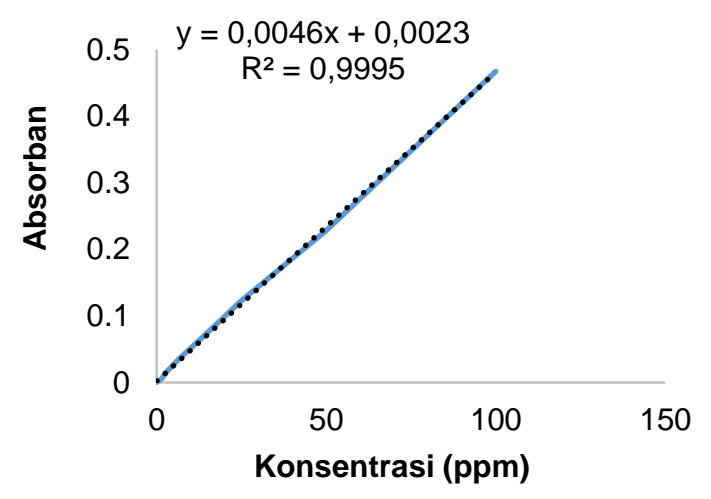

Gambar 7. Kurva standar flavonoid

Berdasarkan pesamaan regresi $\mathrm{y}=$ $0,0046 x+0,0023$, maka dilakukan perhitungan kadar total flavonoid total dan diperoleh kadar flavonoid total dengan parameter uji total flavonoid ekuivalen kuersetin pada sampel ekstrak etanol biji kelor, yaitu 0,255\% (Tabel 2). Flavonoid memiliki aktivitas sebagai antioksidan, diuretik dan dapat menurunkan kadar kolestrol serum (Hanani, 2014).

Berdasarkan penelitian yang telah dilakukan, ekstrak etanol biji kelor memiliki kadar metabolit sekunder lebih rendah dibandingkan dengan penelitian terdahulu pada tanaman Tamoenju, dimana ekstrak etanol biji kelor memiliki kadar total alkaloid 
sebesar $916,87 \mu \mathrm{g} / \mathrm{g}$, flavonoid $0,255 \%$, saponin $6,367 \%$ dan tanin $3.724,5 \mu \mathrm{g} / \mathrm{g}$. Ekstrak daun Tamoenju memiliki kadar metabolit sekunder lebih tinggi yaitu kadar total alkaloid sebesar 15,32\%, flavonoid 14,99 $\mathrm{mg} / 100 \mathrm{~g}$, saponin $6,65 \%$ dan tanin $0,143 \%$ (Alasa et al., 2017). Penelitian terdahulu pada daun Inggu memiliki senyawa flavonoid sebesar $1,67 \%$ dan tanin 7,04\% (Noer et al., 2018) yang menandakan kadar flavonoid dan tanin daun Inggu lebih tinggi dibandingkan dengan ekstrak biji kelor, namun untuk senyawa saponin daun Inggu memiliki kadar total saponin lebih rendah yaitu 2,13\% dibandingkan dengan ekstrak biji kelor. Pada penelitian kulit buah alpukat menunjukan kandungan flavonoid kulit buah alpukat lebih tinggi dari ekstrak biji kelor yaitu sebesar 4,012\% (Aminah et al., 2017). Hal ini dikarenakan keberadaan metabolit sekunder terbatas dan spesifik pada tanaman atau suku tertentu, kandungan metabolit sekunder tergantung dari berbagai faktor biotik dan nonbiotik antara lain suhu, kondisi tanah, iklim dan sinar matahari (Hanani, 2014).

\section{KESIMPULAN}

Berdasarkan hasil penelitian maka dapat disimpulkan bahawa ekstrak etanol biji kelor (Moringa oleifera Lam.) mengandung senyawa metabolit sekunder yaitu alkaloid, tanin,saponin dan flavonoid. Ekstrak etanol biji kelor (Moringa oleifera Lam.) memiliki kadar senyawa alkaloid dengan parameter uji total alkaloid ekuivalen kuinin sebesar $916,87 \mu \mathrm{g} / \mathrm{g}$, senyawa tanin dengan parameter uji total tanin ekuivalen asam tanat sebesar $3.724,5 \mu \mathrm{g} / \mathrm{g}$, senyawa saponin dengan parameter uji total saponin dari Quilaja bark kuantitatif sebesar $6,367 \%$ dan senyawa flavonoid dengan parameter uji total flavonoid ekuivalen kuersetin sebesar $0,255 \%$.
Pada penelitian berikutnya, perlunya dilakukan kajian lebih lanjut terhadap hewan uji untuk mengetahui efek farmakologi ekstrak etanol biji kelor.

\section{DAFTAR PUSTAKA}

Alasa, A. N., Anam, S., \& Jamaluddin, J. (2017). Analisis Kadar Total Metabolit Sekunder Ekstrak Etanol Daun Tamoenju (Hibiscus surattensis L.). KOVALEN: Jurnal Riset Kimia, 3(3): 258-268.

Aminah, A., Tomayahu, N., \& Abidin, Z. (2017). Penetapan Kadar Flavonoid Total Ekstrak Etanol Kulit Buah Alpukat (Persea americana Mill.) Dengan Metode Spektrofotometri UV-VIS. Jurnal Fitofarmaka Indonesia, 4(2): 226-230. https://doi.org/10.33096/jfi.v4i2.265

Anggi, V., Tandi, J., \& Veronika, V. (2020). Total Flavonoid Dan Efektivitas Ekstrak Etanol Biji Kelor (Moringa Oleifera L) Asal Kota Palu Sulawesi Tengah Terhadap Histopatologi Pankreas Tikus Putih Jantan (Rattus norvegicus) Yang Diinduksi Streptozotocin. Jurnal Ilmiah Manuntung, 6(1), 24-31.

Atun, S. (2010). Pemanfaatan Bahan Alam Bumi Indonesia Menuju Riset Yang Berkualitas Internasional. Prosiding Seminar Nasional Kimia. Seminar Nasional Kimia, Yogyakarta. http://staffnew.uny.ac.id/upload/13187395 6/penelitian/Pemanfaatan+bahan+alam+1 ndonesia+menuju+riset+yang+berkualitas +internasional-SemNas+Kimia-2010.pdf

Chanwitheesuk, A., Teerawutgulrag, A., \& Rakariyatham, N. (2005). Screening of antioxidant activity and antioxidant compounds of some edible plants of Thailand. Food Chemistry, 92(3): 491497.

https://doi.org/10.1016/j.foodchem.2004.0 7.035

Ergina, Nuryanti, S., \& Pursitasari, I. (2014). Uji Kualitatif Senyawa Metabolit Sekunder Pada Daun Palado (Agave angustifolia) Yang Diekstraksi Dengan Pelarut Air Dan Etanol. J. Akad. Kim., 3(3): 165-172. 
Hanani, E. (2014). Analisis Fitokimia. Buku Kedokteran ECG, Jakarta.

Harborne, J., Padmawinata, K., \& Soediro, I. (2006). Metode Fitokimia Penuntun cara modern menganalisis tumbuhan. ITB, Bandung.

Noer, S., Pratiwi, R., \& Gresinta, E. (2018). Penetapan Kadar Senyawa Fitokimia (Tanin, Saponin dan Flavonoid) sebagai Kuersetin Pada Ekstrak Daun Inggu (Ruta angustifolia L.). Jurnal Eksakta, 18(1): 1929. https://doi.org/10.20885/eksakta.vol18.iss 1.art3

Salimi, Y. K., Bialangi, N., \& Saiman, S. (2017). Isolasi Dan Identifikasi Senyawa Metabolit Sekunder Ekstrak Metanol Daun Kelor (Moringa oleifera Lamk.). Akademika, 6(2), Article 2. https://doi.org/10.31314/akademika.v6i2.5 4

Saxena, G., \& Kalra. (2011). Antimicronial Activity Pattern of Certain Terpenoids. Internasional Journal of Pharma and Bio Sciences, 2(1): 87-91.

Septyaningsih, D. (2010). Isolasi dan identifikasi komponen utama ekstrak biji buah merah ( Pandanus conoideus lamk). [Skripsi]. FMIPA Universitas Sebelas Maret, Surakarta.

Simaremare, E. S. (2014). Skrining Fitokimia Ekstrak Etanol Daun Gatal (Laportea decumana (Roxb.) Wedd). PHARMACY, 11(1): 98-107. 